\title{
Identify Potentiality of Establishing an Ecotourism Region by Linking Horton Plains, Babarakanda and Lanka Water Falls
}

\author{
Nandasena W.D.K.V.* \\ Sabaragamuwa University of Sri Lanka, Belihuloya Sri Lanka \\ *kalpani.nanadasena@gmail.com
}

\begin{abstract}
Tourism is one of the biggest service industry with different aspects in the world. Ecotourism is present tendency with the concept of sustainability. It is a purposeful travel to natural areas to understand the culture and natural history of the environment taking care not to alter the integrity of the ecosystem while producing economic opportunities that make conservation of natural resources beneficial to local people.
\end{abstract}

This study conducted to identify potentiality of creating ecotourism region by connecting Horton plains, Babarakanda and Lanka waterfalls. As sub objectives identify resources needed to establish ecotourism region and ways of tourism service can improve in this region. In each district, Badulla and Nuwara Eliya two G.N divisions were selected as study area namely Kalupahana, Weerakoongama and Loinan, Pattipola respectively. To tackle down above objectives questionnaire survey was carried out for both villagers and local as well as foreign tourists. Sample size was 50 for villagers than 50 and 20 for local and foreign tourists respectively. Chi square test and weighted overlay technique in ArcGIS used to analyse collected data. According to Pearson's chi square test following relationships were identified: development in tourism have a relationship with economic development and regional development in the area. As well to enhance opportunities of employment and income ways and also for develop infrastructures in study area with $0.001,0.036,0.000,0.000$ and 0.002 significance levels respectively under the $95 \%$ confidence level. Roadmap, vegetation cover map and tourist site map were used to generate suitable ecotourism regions map. It revealed North, West and Southwest of study area were more suitable as ecotourism region because of many small waterfalls with large waterfalls such as Babarakanda and Lanka waterfalls besides its vegetation cover and Horton plain's biodiversity.77\% of tourism attraction sites located this region while remaining locations scattered around the lower suitable areas. Study area support for tourist activities such as hiking, plant investigation, mountain climbing etc. Interconnectivity between tourist hot spots must develop and same time improvement of infrastructures and services must provide in order to have a productive ecotourism region.

Keywords: Eco-tourism region, Babarakanda and Lanka water falls, Horton plains, Weighted overlay technique 